Vol. 11, No. 40, July, 2016, 943-953

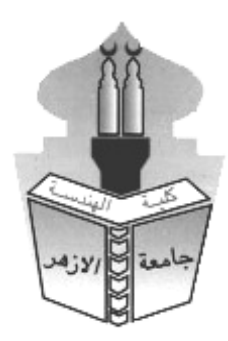

\title{
EFFECT OF FIRE EXPOSURE ON AXIALLY AND BIAXIALLY LOADED REINFORCED CONCRETE COLUMNS
}

\author{
A. A. Shaheen, H. A. Dahish , A.S.Farid and M. A. Abdul-Hady \\ Fayoum University, Faculty of Engineering, Civil Department, Egypt.
}

\begin{abstract}
This paper presents the analytical investigation on the residual load capacity of reinforced concrete columns subjected to elevated temperature under axial and biaxial loads. The aims of the analytical program are verifying of the proposed numerical model and presenting a parametric study by using FEA program ANSYS V.13 for studying the effects of the concrete characteristic strength, rectangularity ratio, eccentricity ratio, and fire duration. Twenty-seven full-size columns models, which using ANSYS elements (Solid65, Solid70, Link8, and Link33), were constructed and subjected to axial and biaxial loads after fire exposure according to the ISO 834 standard fire curve. The firing time exposure are at room temperature, 1.5 hours and 3 hours. A comparison between the numerical predictions and the test results shows good agreements. The numerical results indicated that, the residual load capacity is directly proportional to the concrete characteristic strength. The column residual load capacity increased by increasing the concrete characteristic strength. The column residual load capacity decreased by increasing the rectangularity ratio and increasing firing duration.
\end{abstract}

Keywords: Reinforced Concrete, Columns, Elevated Temperature, Axial Load, Biaxial Bending, FEA, ANSYS

\section{INTRODUCTION}

Concrete structures generally behave well in fires. Most of the fire damaged of RC buildings can be repair and reused even after severe fires. When concrete exposed to heat, chemical and physical responses occur at elevated temperatures, such as loss of moisture, dehydration of cement paste and decomposition of aggregate. These changes will bring a breakdown in the structure of concrete, affecting its mechanical properties. Therefore, RC members without visible damage may have reduced strength and stiffness due to elevated temperatures. To repair the fire damaged $\mathrm{RC}$ members, it is essential to have a practical analytical approach to evaluate the residual strength and stiffness of RC members after fire events.

Many investigators had studied the R.C. columns under elevated temperature. Mohammed Kadhum (2013) [1] studied experimentally the effect of burning by fire flame on the behavior and load carrying capacity of reinforced concrete columns. Nikhil Raut (2011) [2] presented fire resistance experiments on RC columns, with and without fibers, under standard and design fire scenarios to evaluate the behavior under different parameters and develop a comprehensive macroscopic finite element based model for predicting the response of RC columns under realistic fire, loading and failure conditions. Farid, A.S., (2011) [3] studied experimentally and numerically using FEA program ANSYS the effect of fire exposure on the behaviour of reinforced concrete columns under axial and eccentric loads. M. Mohamed Bikhiet (2004) [4] presented an experimental work to study columns exposed to fire under axial load and to evaluate reduction in column compressive capacity after fire. W. Mohamed (2004) [5] 
studied experimentally the behaviour of biaxially and uniaxially loaded HSC square short columns strengthened with externally applied FRP laminates. M.T.El-Mihilmy (1992) [6] studied experimentally the behaviour and design of R.C.short columns Under biaxial bending. Lin, C.H and Chen, S.T of NTUST $(1990,1988)[8,9]$ conducted a series of experimental studies in this area, such as the residual strength and stiffness of fire damaged columns under uniaxial and biaxial loading. Lie, T.T.(1983)[10] established the thermal conductivity model and experimentally studied the effect of axial loading, size of cross section, moisture content, and the types of aggregate on the residual strength of concrete columns. $\mathrm{He}$ also used the ultrasonic method and numerical calculations to determine the residual strength of the $\mathrm{RC}$ columns

\section{VERIFICATION OF EXPERIMENTAL RESULTS BY USING THE FINITE ELEMENT MODEL (ANSYS)}

The main objective of the verification is to verify the proposed numerical model.

A comparison of the results from the ANSYS finite element analysis with the experimental data for the reinforced concrete columns tested by Mohammed M.Kadhum (2013) [1], Nikhil Raut (2011) [2], Farid, A.S., (2011) [3], M. Mohamed Bikhiet (2004) [4], W.Mohamed (2004) [5], and M.T.El-Mihilmy (1992) [6] is carried out. The dimensions and details of reinforcement for all specimens, load eccentricities and the material properties are shown in table (1).

Table (1): Description of finite element column model

\begin{tabular}{|c|c|c|c|c|c|c|c|c|c|c|}
\hline $\begin{array}{c}\text { Group } \\
\text { No. }\end{array}$ & $\begin{array}{l}\text { Reference } \\
\text { Name }\end{array}$ & $\begin{array}{l}\text { Col. } \\
\text { No }\end{array}$ & $\begin{array}{l}\text { Col. } \\
\text { Dim } \\
\text { mm } \\
\end{array}$ & $\underset{\mathbf{m m}}{\mathbf{H}}$ & $\underset{\mathbf{N} / \mathbf{m m}^{2}}{\mathbf{F}_{\mathrm{cu}}}$ & R.F.T & $\begin{array}{c}\text { Stirrups } \\
\text { mm }\end{array}$ & $\mathbf{e}_{\mathrm{x}} \mathbf{m m}$ & $\begin{array}{c}\mathbf{e}_{\mathbf{y}} \\
\mathbf{m m}\end{array}$ & $\begin{array}{l}\text { Fire } \\
\text { Time } \\
\text { (min) } \\
\end{array}$ \\
\hline \multirow{5}{*}{ 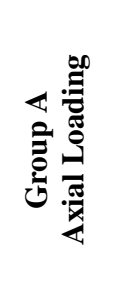 } & \multirow{3}{*}{$\begin{array}{c}\text { Bikhiet } \\
\text { (2004) }\end{array}$} & AN1 & $150 * 150$ & 1000 & 30 & $4 \Phi 10$ & Ф6@100mm & 0 & 0 & - \\
\hline & & AE1 & $150 * 150$ & 1000 & 30 & $4 \Phi 10$ & Ф6@100mm & 0 & 0 & 10 \\
\hline & & AE2 & $150 * 150$ & 1000 & 30 & $4 \Phi 10$ & Ф10@100mm & 0 & 0 & 20 \\
\hline & \multirow{2}{*}{$\begin{array}{l}\text { Nikhil } \\
\text { Raut } \\
(\mathbf{2 0 1 1})\end{array}$} & AE3 & $305 * 305$ & 3800 & 34.8 & $4 Ф 25$ & Ф10@100mm & 0 & 0 & 218 \\
\hline & & AE4 & $406 * 406$ & 3800 & 75 & $8 \Phi 25$ & Ф6@100mm & 0 & 0 & 299 \\
\hline \multirow{3}{*}{ 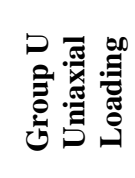 } & \multirow{3}{*}{$\begin{array}{c}\text { Farid, A. } \\
\text { S., } \\
(2011)\end{array}$} & UN1 & $200 * 200$ & 1000 & 25 & $6 \Phi 12$ & Ф3@100mm & 40 & 0 & - \\
\hline & & UE1 & $200 * 200$ & 1000 & 25 & $6 \Phi 12$ & Ф3@100mm & 40 & 0 & 25 \\
\hline & & UE2 & $200 * 200$ & 1000 & 25 & $6 \Phi 12$ & Ф3@100mm & 40 & 0 & 40 \\
\hline \multirow{7}{*}{ ص } & \multirow{2}{*}{$\begin{array}{c}\text { El- } \\
\text { Mihilmy } \\
(\mathbf{1 9 9 2 )}\end{array}$} & BN1 & $250 * 250$ & 1800 & 35.4 & $4 \Phi 13$ & Ф8@175mm & 125 & 125 & - \\
\hline & & BN2 & $250 * 250$ & 1800 & 35.5 & $8 \Phi 13$ & Ф8@175mm & 125 & 125 & - \\
\hline & $\begin{array}{c}\text { Weal } \\
(2004) \\
\end{array}$ & $\mathrm{BN} 3$ & $200 * 200$ & 1850 & 30 & $4 \Phi 16$ & Ф8@190mm & 25 & 25 & \\
\hline & \multirow{2}{*}{$\begin{array}{c}\text { Kadhum } \\
(2013)\end{array}$} & BE1 & $150 * 150$ & 1500 & 30 & $4 \Phi 10$ & Ф8@150mm & 30 & 30 & 90 \\
\hline & & BE2 & $150 * 150$ & 1500 & 40 & $4 \Phi 10$ & Ф8@150mm & 30 & 30 & 90 \\
\hline & \multirow{2}{*}{$\begin{array}{l}\text { Nikhil } \\
\text { Raut } \\
\text { (2011) }\end{array}$} & BE3 & $305 * 305$ & 3800 & 35.7 & $4 \Phi 25$ & Ф10@100mm & 24 & 24 & 181 \\
\hline & & BE4 & $406 * 406$ & 3800 & 127 & $8 Ф 25$ & Ф6@100mm & 25 & 25 & 118 \\
\hline
\end{tabular}

Note: $\mathrm{A}=$ Axial Load, $\mathrm{U}=$ Uniaxial Load, $\mathrm{B}=$ Biaxial Load, $\mathrm{E}=$ Exposed to Fire, $\mathrm{N}=$ Not Exposed to Fire.

\subsection{Finite Element Model by ANSYS}

\subsubsection{Concrete Element}

In this research, two solid elements are used to define the concrete in ANSYS code [11]. The concrete was modeled by solid65 and the element of solid65 was converted to solid70 to present the thermal element. 


\subsubsection{Solid65 Input Data}

1-Temperature degree

2- Elastic modulus.

3- Ultimate uniaxial compressive strength

4- Ultimate uniaxial tensile strength

5- Poisson's ratio (U) for concrete

6- Shear transfer coefficient $(\beta o)$ for open cracks and $(\beta c)$ for closed cracks,

\subsubsection{Solid70 Input Data}

1- Thermal capacity

2- Thermal conductivity

3- Thermal diffusivity

4- Thermal expansion

\subsubsection{Steel Element}

\subsubsection{Reinforcing Steel Bars}

LINK8 is a spar that can be used in a variety of engineering applications. This element can be used to model trusses, sagging cables, links, springs, etc. This 3-D spar element is a uniaxial tension-compression element with three degrees of freedom at each node: translations in the nodal $\mathrm{x}, \mathrm{y}$, and $\mathrm{z}$ directions.

The steel for the finite element models was assumed to be an elastic perfectly plastic material, and the strength was defined according to the data in the test.

\subsection{Results and Discussions}

Table (2) shows two results of the crushing load failure before exposed to elevated temperature and residual load capacity for firing columns model from experimental data obtained from literature.

Figure (1) shows the comparison between numerical and experimental results.

The present model successfully estimated the failure load of the columns. By analyzing, we found that the max $\%$ difference ratio from the comparative study between experimental test results and numerical results is $5.70 \%$, which show good agreement with test results.

Therefore, the proposed model could be used for modeling as built columns in order to propose a suitable design.

Table (2): Comparison between experimental and numerical analysis

\begin{tabular}{|c|c|c|c|}
\hline \multirow{2}{*}{$\begin{array}{l}\text { Column } \\
\text { No. }\end{array}$} & \multicolumn{2}{|c|}{$\underset{(k N)}{\operatorname{Maximum~Load~}}$} & \multirow{2}{*}{$\begin{array}{c}\text { \% Difference } \\
\text { Ratio }\end{array}$} \\
\hline & $\begin{array}{c}\text { Test } \\
\text { value }\end{array}$ & $\begin{array}{c}\text { ANSYS } \\
\text { value }\end{array}$ & \\
\hline AN1 & 705 & 703 & $0.28 \%$ \\
\hline AE1 & 600 & 626 & $-4.33 \%$ \\
\hline AE2 & 530 & 550 & $-3.77 \%$ \\
\hline AE3 & 800 & 834 & $-4.25 \%$ \\
\hline AE4 & 3895 & 4034 & $-3.69 \%$ \\
\hline UN1 & 545 & 557 & $-2.20 \%$ \\
\hline UE1 & 450 & 444 & $1.33 \%$ \\
\hline UE2 & 395 & 390 & $1.27 \%$ \\
\hline BN1 & 350 & 365 & $-4.29 \%$ \\
\hline BN2 & 425 & 421 & $1.03 \%$ \\
\hline BN3 & 655 & 633 & $3.43 \%$ \\
\hline BE1 & 241 & 249 & $-3.32 \%$ \\
\hline BE2 & 261 & 259 & $0.77 \%$ \\
\hline BE3 & 1000 & 1057 & $-5.70 \%$ \\
\hline BE4 & 4981 & 5113 & $-2.65 \%$ \\
\hline
\end{tabular}



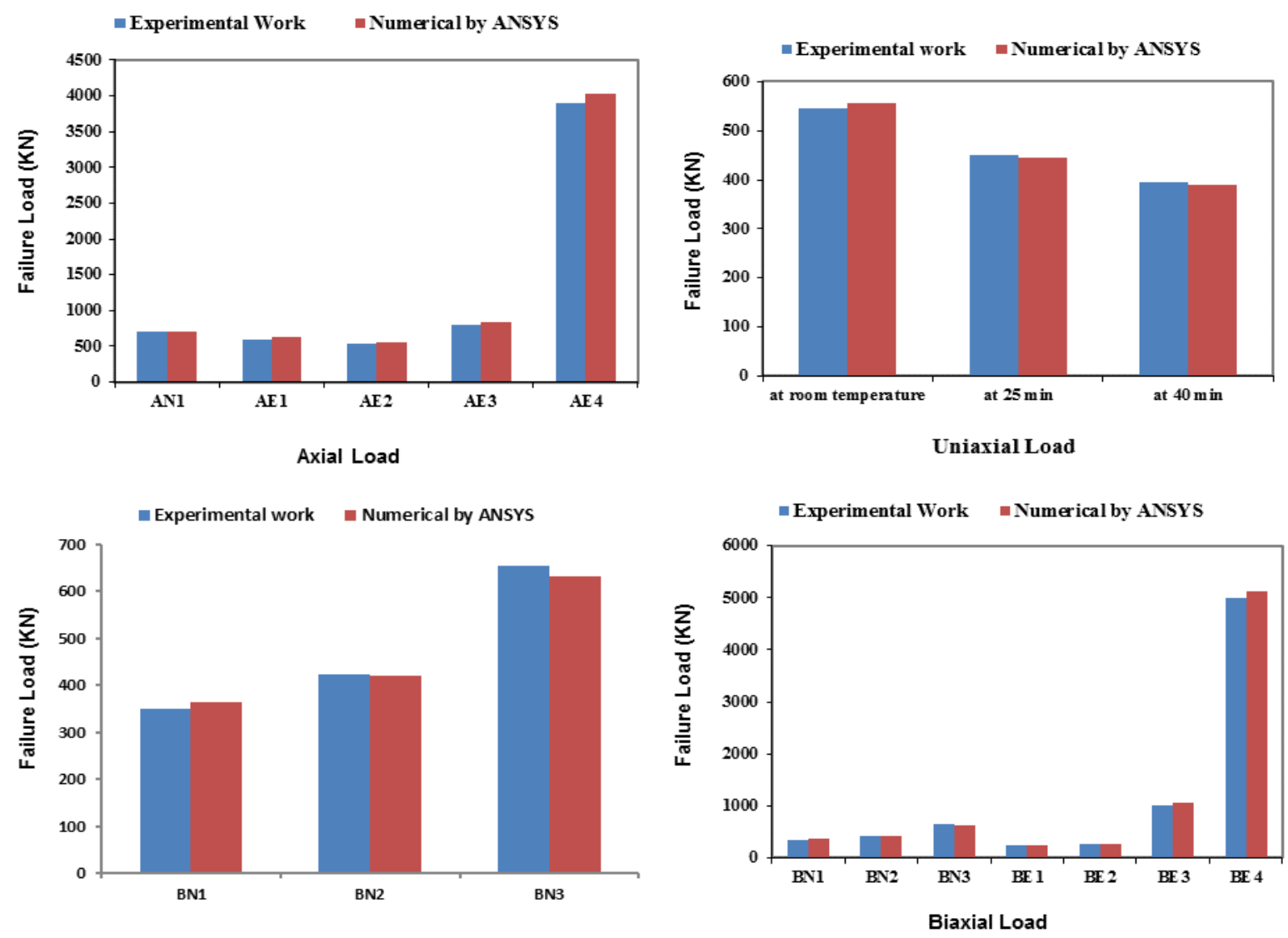

Figure (1): Comparisons between experimental work and ANSYS model results

\section{Finite Element Analysis Program}

\subsection{Input Data finite element model by ANSYS}

\subsubsection{Solid65}

1-Temperature degree $\left(\mathrm{T}=650^{\circ} \mathrm{C}\right)$

2- Elastic modulus $\left(\mathrm{E}_{\mathrm{c}}=4700 \sqrt{\mathrm{fc}} \mathrm{c}^{\prime}\right) \mathrm{MPa}$.

3- Ultimate uniaxial compressive strength

$\left(\mathrm{fc}^{\prime}=25,35\right.$, and 45$) \mathrm{N} / \mathrm{mm}^{2}$.

4- Ultimate uniaxial tensile strength $(\mathrm{ft}=0.1 \mathrm{fc}$ ').

5- Poisson's ratio $(\mathrm{U})$ for concrete $\mathrm{U}=0.2$.

6- Shear transfer coefficient ( $\beta \mathrm{o})$ for open cracks and $(\beta \mathrm{c})$ for closed cracks, representing conditions of crack face for determining the amount of shear transfer across the crack were used. In present study, ( $\beta$ o) was assumed to be $(0.2)$ while $(\beta \mathrm{c})$ was $(0.4)$.

\subsubsection{Solid70}

1- Thermal capacity $(\mathrm{C}=860.3) \mathrm{J} / \mathrm{Kg}^{\circ} \mathrm{K}$

2- Thermal conductivity $(\mathrm{K}=1.873) \mathrm{W} / \mathrm{m}{ }^{\circ} \mathrm{K}$

3- Thermal diffusivity $(\mathrm{D}=0.00356) \mathrm{m}^{2} / \mathrm{hr}$

4- Thermal expansion $\left(6.31 \times 10^{-6}\right)$

\subsubsection{Steel Element (LINK8)}

The steel for the finite element models was assumed to be an elastic perfectly plastic material, and the strength was defined according to the data in the test. The used steel grade is $36 / 52$. Material properties for the steel 
reinforcement for all models are as follows; Elastic modulus $\left(E s=200000 \mathrm{~N} / \mathrm{mm}^{2}\right)$, Yield stress $(\mathrm{F} y=360$ $\mathrm{N} / \mathrm{mm}^{2}$ ) and Poisson's ratio $(\mathrm{U})$ for steel $\mathrm{U}=0.3$

\subsection{Parameters of the Numerical Analysis}

A parametric study of twenty-seven columns of 3000mm long was conducted to investigate the effect of the following variables; concrete characteristic strength $\left(\mathrm{F}_{\mathrm{cu}}=25,35\right.$, and $\left.45 \mathrm{~N} / \mathrm{mm}^{2}\right)$, the cross section $400 \mathrm{mmx} 400 \mathrm{~mm}$, eccentricity ratio $(\mathrm{e} / \mathrm{t}=0 \%, 25 \%$, and $40 \%)$ and fire duration (At room temperature, and exposure duration of 1.5, and $3 \mathrm{hr}$ to temperature at $650^{\circ} \mathrm{C}$ ). The details of each column were listed in Table 3 .

Figure (2) show the Column Cross Section, Reinforcement Details and Finite Element Mesh and Steel Mesh for Column Model. Column load and column residual load after exposed to elevated temperature were obtained at each load step; first crack loads, deformed shape and failure mode are obtained for each column at failure load.

Table (3): Description of finite element column model

\begin{tabular}{|c|c|c|c|c|c|}
\hline $\begin{array}{c}\text { Group } \\
\text { No. }\end{array}$ & $\begin{array}{l}\text { Col. } \\
\text { No }\end{array}$ & R.F.T & $\begin{array}{c}\text { Stirrups } \\
\text { mm. }\end{array}$ & $\mathrm{e} / \mathrm{t} \%$ & $\begin{array}{c}\text { Fire } \\
\text { Time } \\
\text { (hr) }\end{array}$ \\
\hline \multirow{9}{*}{ 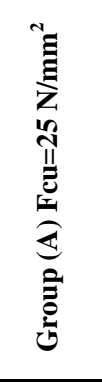 } & A1a1 & $8 \Phi 16$ & Ф8@100mm & 0 & 0 \\
\hline & A1a2 & $8 \Phi 16$ & $\Phi 8 @ 100 \mathrm{~mm}$ & 0 & 1.5 \\
\hline & A1a3 & $8 \Phi 16$ & Ф8@100mm & 0 & 3 \\
\hline & A1b11 & $8 \Phi 16$ & Ф8@100mm & 25 & 0 \\
\hline & A1b12 & $8 \Phi 16$ & Ф8@100mm & 25 & 1.5 \\
\hline & A1b13 & $8 \Phi 16$ & $\Phi 8 @ 100 \mathrm{~mm}$ & 25 & 3 \\
\hline & A1b21 & $8 \Phi 16$ & Ф8@100mm & 40 & 0 \\
\hline & A1b22 & $8 \Phi 16$ & Ф8@100mm & 40 & 1.5 \\
\hline & A1b23 & $8 \Phi 16$ & Ф8@100mm & 40 & 3 \\
\hline \multirow{9}{*}{ 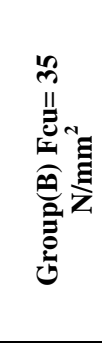 } & B1a1 & $8 \Phi 16$ & Ф8@100mm & 0 & 0 \\
\hline & B1a2 & $8 \Phi 16$ & Ф8@100mm & 0 & 1.5 \\
\hline & B1a3 & $8 \Phi 16$ & Ф8@100mm & 0 & 3 \\
\hline & B1b11 & $8 \Phi 16$ & $\Phi 8 @ 100 \mathrm{~mm}$ & 25 & 0 \\
\hline & B1b12 & $8 \Phi 16$ & Ф8@100mm & 25 & 1.5 \\
\hline & B1b13 & $8 \Phi 16$ & Ф8@100mm & 25 & 3 \\
\hline & B1b21 & $8 \Phi 16$ & Ф8@100mm & 40 & 0 \\
\hline & B1b22 & $8 \Phi 16$ & Ф8@100mm & 40 & 1.5 \\
\hline & B1b23 & $8 \Phi 16$ & Ф8@100mm & 40 & 3 \\
\hline \multirow{9}{*}{ 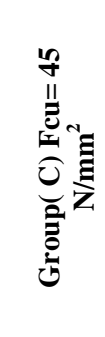 } & C1a1 & $8 \Phi 16$ & Ф8@100mm & 0 & 0 \\
\hline & C1a2 & $8 \Phi 16$ & Ф8@100mm & 0 & 1.5 \\
\hline & C1a3 & $8 \Phi 16$ & Ф8@100mm & 0 & 3 \\
\hline & C1b11 & $8 \Phi 16$ & Ф8@100mm & 25 & 0 \\
\hline & C1b12 & $8 \Phi 16$ & Ф8@100mm & 25 & 1.5 \\
\hline & C1b13 & $8 \Phi 16$ & Ф8@100mm & 25 & 3 \\
\hline & C1b21 & $8 \Phi 16$ & Ф8@100mm & 40 & 0 \\
\hline & C1b22 & $8 \Phi 16$ & Ф8@100mm & 40 & 1.5 \\
\hline & C1b23 & $8 \Phi 16$ & Ф8@100mm & 40 & 3 \\
\hline
\end{tabular}



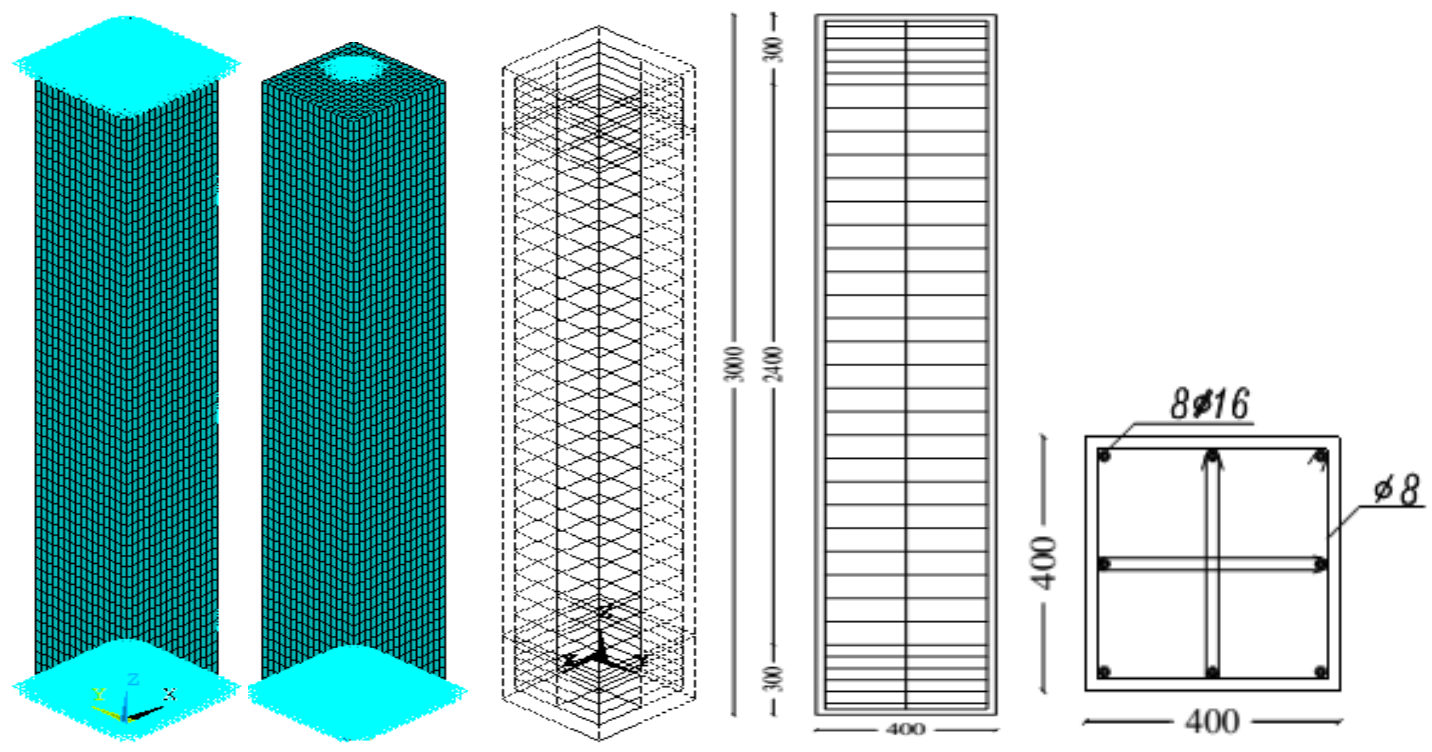

Figure (2): Column cross section, reinforcement details, finite element mesh and steel mesh for column model $(400 \mathrm{~mm} \times 400 \mathrm{~mm})$

\subsection{Temperature Effect and Equivalent Model Exposure Time}

Figure (3) shows the ISO-834 standard time-temperature curve [7] used in the current study. The timetemperature relationship on the boundary member is defined in equation (1).

$$
T_{b}=345 \times \log _{10}(8 \mathrm{t}+1)+T_{0}
$$

Where

$\mathrm{t}$ is time [min].

$T_{O}$ is ambient temperature $\left[{ }^{\circ} \mathrm{C}\right]$.

$T_{b}$ is boundary temperature $\left[{ }^{\circ} \mathrm{C}\right]$.

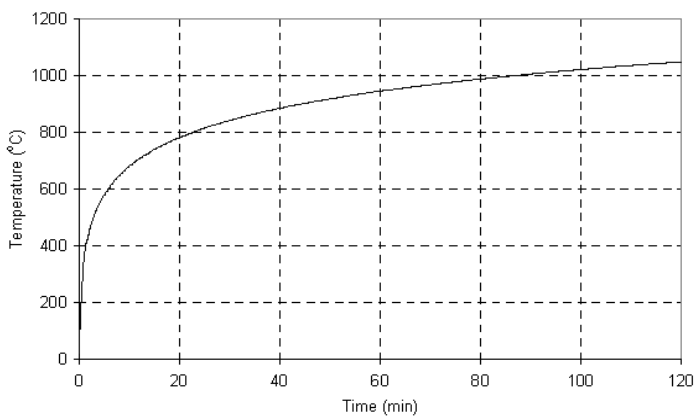

Figure (3): Standard ISO 384 firing curve

\section{RESULTS AND ANALYSIS}

\subsection{Results}

All of tested models were classified into three cases of a firing exposure, the reference column was A1a1 at room temperature condition while second and third case are at temperature $650^{\circ} \mathrm{C}$ after firing time of $1.5 \mathrm{hr}$, and $3 \mathrm{hr}$ as mentioned before. The results of each column were listed in Table 4.

Table 5 show the Percentage of the residual load capacity for columns with different concrete characteristic strengths at different firing times under axial and biaxial loads

Figure (4) shows the effect of different concrete characteristic strength on columns residual load capacity at different firing cases.

Figure (5) shows first crack and deformed shape for sample of column models before and after exposure to fire.

Figure (6) shows the temperature distribution fire of column cross sections. 
Table (4): Results of all columns

\begin{tabular}{|c|c|c|c|c|}
\hline $\begin{array}{c}\text { Group } \\
\text { No. }\end{array}$ & Col.No. & $\begin{array}{c}\text { Correct } \\
\text { Load KN }\end{array}$ & $\begin{array}{c}\text { Ansys } \\
\text { \% Residual } \\
\text { Load }\end{array}$ & e/t \% \\
\hline \multirow{9}{*}{ 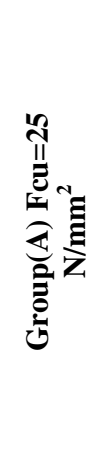 } & A1a1 & 4204 & 100 & 0 \\
\hline & A1a2 & 2825 & 67.20 & 0 \\
\hline & A1a3 & 2233 & 53.12 & 0 \\
\hline & A1b11 & 1368 & 32.54 & 25 \\
\hline & A1b12 & 835 & 19.86 & 25 \\
\hline & A1b13 & 642 & 15.27 & 25 \\
\hline & A1b21 & 855 & 20.34 & 40 \\
\hline & A1b22 & 468 & 11.13 & 40 \\
\hline & A1b23 & 351 & 8.35 & 40 \\
\hline \multirow{9}{*}{ 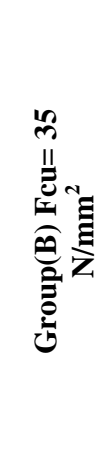 } & B1a1 & 4851 & 115 & 0 \\
\hline & B1a2 & 3469 & 82.52 & 0 \\
\hline & B1a3 & 2732 & 64.99 & 0 \\
\hline & B1b11 & 1803 & 42.89 & 25 \\
\hline & B1b12 & 1155 & 27.47 & 25 \\
\hline & B1b13 & 887 & 21.10 & 25 \\
\hline & B1b21 & 1161 & 27.62 & 40 \\
\hline & B1b22 & 667 & 15.87 & 40 \\
\hline & B1b23 & 515 & 12.25 & 40 \\
\hline \multirow{9}{*}{ 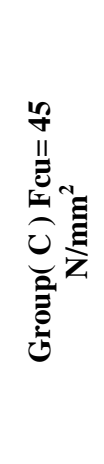 } & C1a1 & 6658 & 158 & 0 \\
\hline & C1a2 & 5113 & 122 & 0 \\
\hline & C1a3 & 4023 & 95.69 & 0 \\
\hline & C1b11 & 2406 & 57.23 & 25 \\
\hline & C1b12 & 1656 & 39.39 & 25 \\
\hline & C1b13 & 1308 & 31.11 & 25 \\
\hline & C1b21 & 1580 & 37.58 & 40 \\
\hline & C1b22 & 988 & 23.50 & 40 \\
\hline & C1b23 & 827 & 19.67 & 40 \\
\hline
\end{tabular}



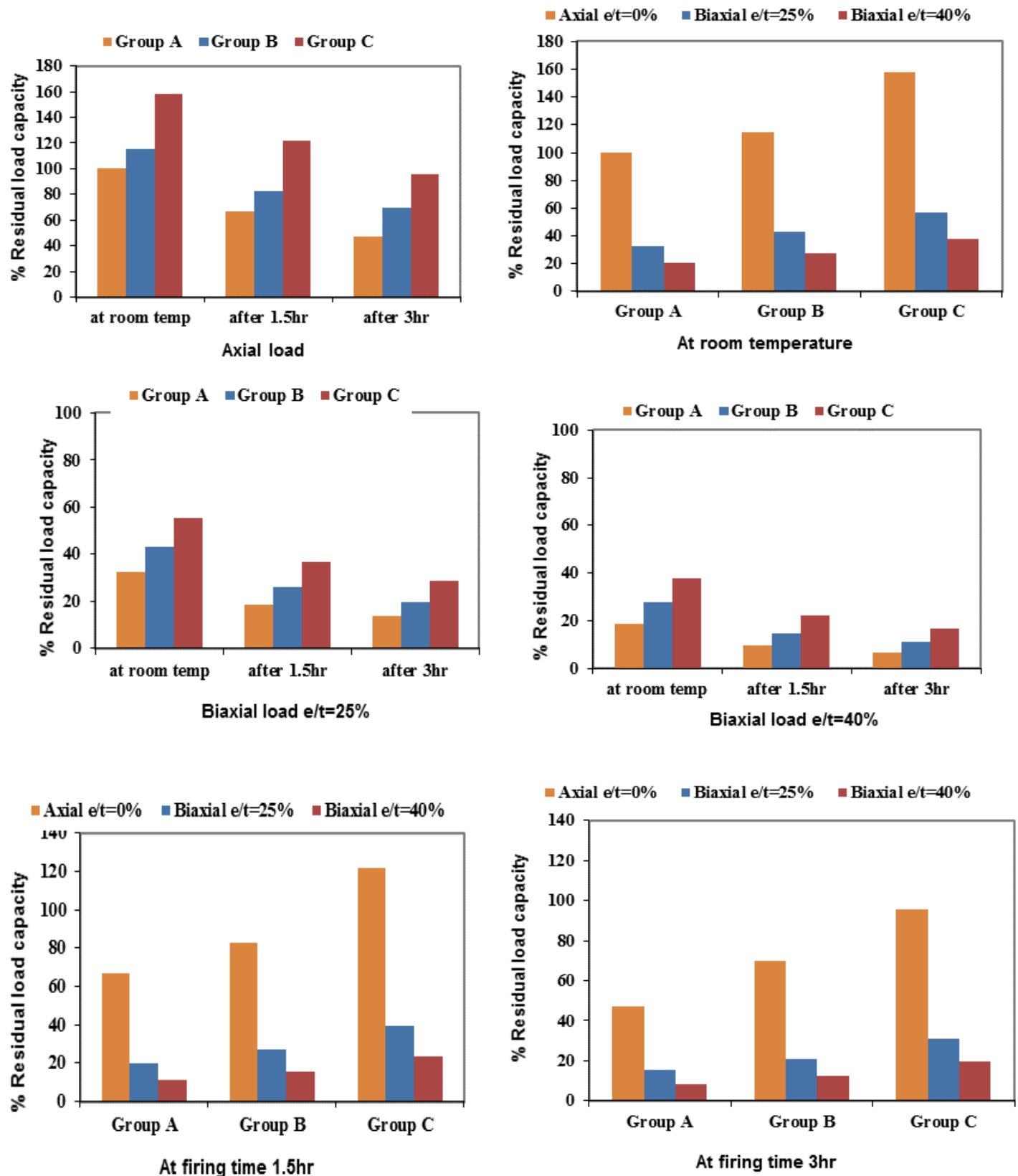

Figure (4): The effect of different concrete characteristic strength on residual load capacity of all columns groups at different firing cases 


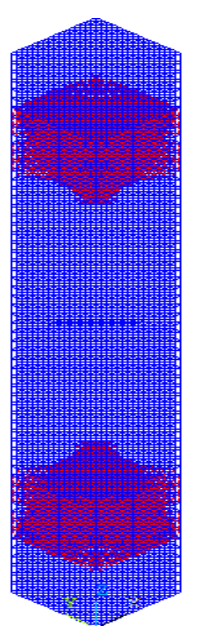

A1a1

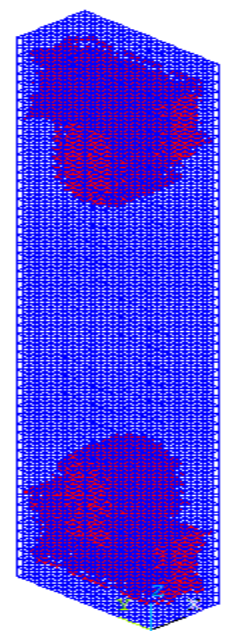

A2a1

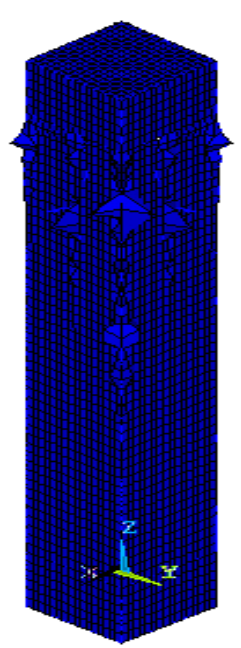

A1b12

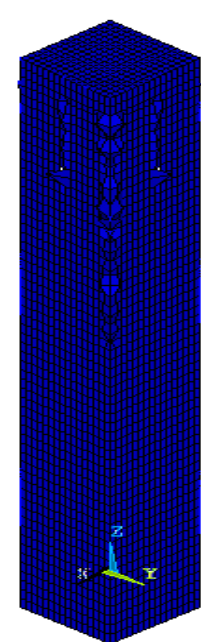

B1b12

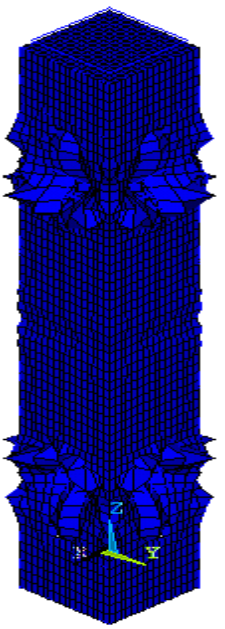

A1a3

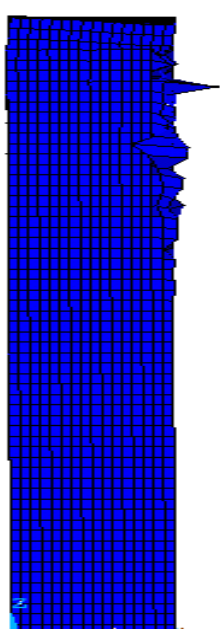

C1b23

Figure (5): Sample for first crack and deformed shape for model column before and after exposure to fire

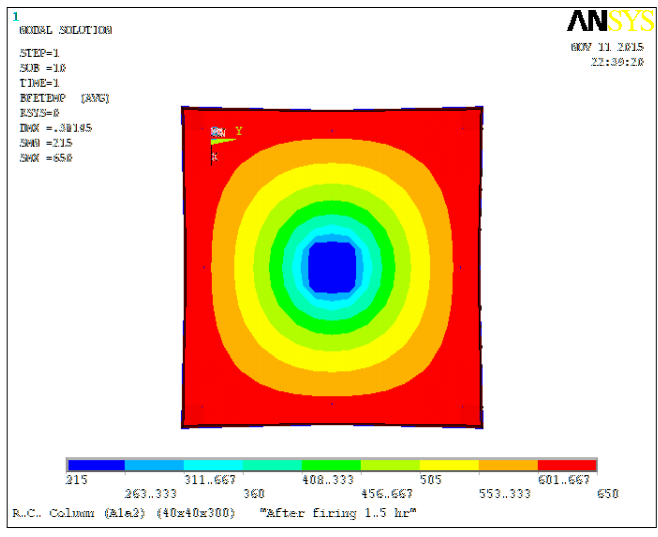

A1 at 1.5hr

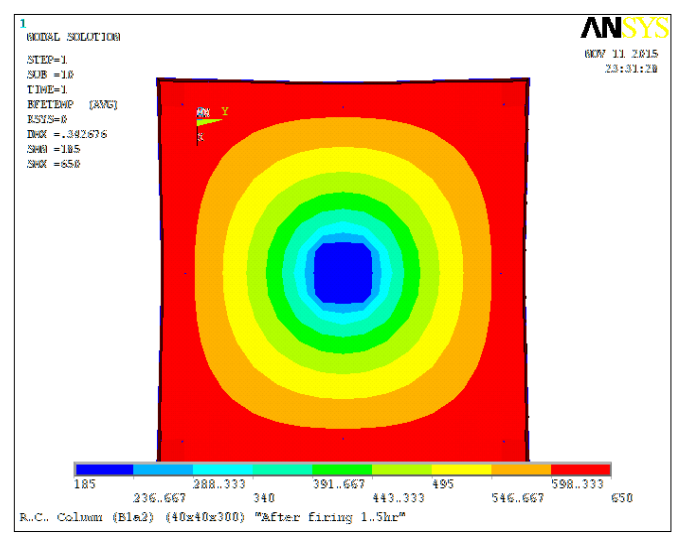

B1 at 1.5hr

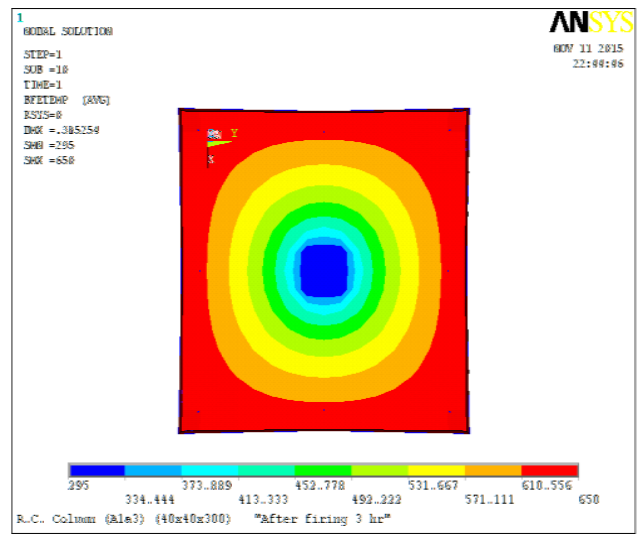

A1 at 3hr

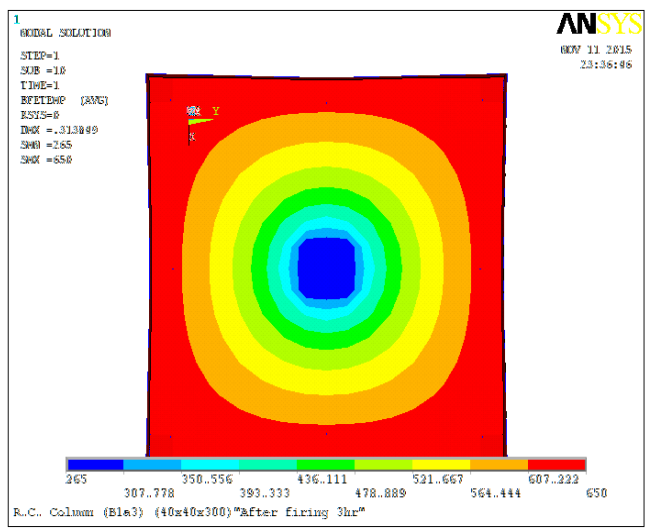

B1 at 3hr 


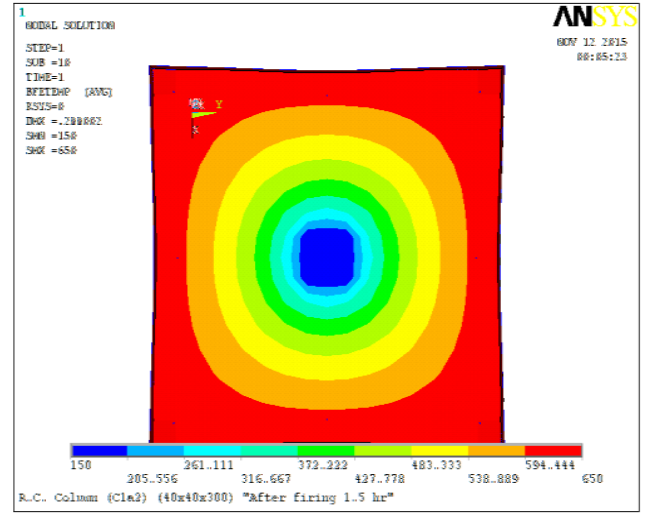

C1 at 1.5hr

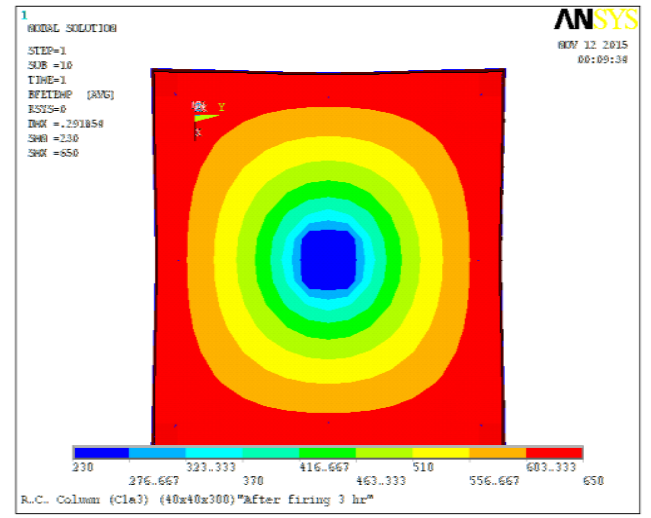

C1 at 3hr

Figure (6): Temperature distribution for column $(400 \times 400 \mathrm{~mm})$ in all groups

Table (5): Percentage of the residual load capacity for columns with different concrete characteristic strengths at different firing times under axial and biaxial loads

\begin{tabular}{|c|c|c|c|c|c|c|c|c|c|}
\hline \multirow[b]{2}{*}{$\begin{array}{l}\text { Loading } \\
\text { Type }\end{array}$} & \multicolumn{3}{|c|}{ Group A $\left(F_{c u}=25 \mathrm{~N} / \mathrm{mm}^{2}\right)$} & \multicolumn{3}{|c|}{ Group B $\left(F_{\mathrm{cu}}=35 \mathrm{~N} / \mathrm{mm}^{2}\right)$} & \multicolumn{3}{|c|}{ Group $C\left(F_{\mathrm{cu}}=45 \mathrm{~N} / \mathrm{mm}^{2}\right)$} \\
\hline & $\begin{array}{c}\text { At room } \\
\text { temperatur } \\
\text { e }\end{array}$ & At $1.5 \mathrm{hr}$ & $\begin{array}{l}\text { At } \\
3 \mathrm{hr}\end{array}$ & $\begin{array}{c}\text { At room } \\
\text { temperatur } \\
\text { e }\end{array}$ & At $1.5 \mathrm{hr}$ & $\begin{array}{l}\text { At } \\
3 \mathrm{hr}\end{array}$ & $\begin{array}{c}\text { At room } \\
\text { temperatur } \\
\text { e }\end{array}$ & $\begin{array}{c}\text { At } \\
1.5 \mathrm{hr}\end{array}$ & $\begin{array}{l}\text { At } \\
3 \mathbf{h r}\end{array}$ \\
\hline Axial Load & $\begin{array}{l}100 \% \\
\text { reference } \\
\text { column }\end{array}$ & $67.20 \%$ & $46.88 \%$ & $\begin{array}{c}115 \\
\%\end{array}$ & $82.52 \%$ & $\begin{array}{c}69.99 \\
\%\end{array}$ & $\begin{array}{c}158 \\
\%\end{array}$ & $\begin{array}{c}122 \\
\%\end{array}$ & $\begin{array}{c}95.69 \\
\%\end{array}$ \\
\hline $\begin{array}{c}\text { Biaxial } \\
\text { Load } \\
\text { e/t=25\% }\end{array}$ & $\begin{array}{c}32.54 \\
\%\end{array}$ & $19.86 \%$ & $15.27 \%$ & $\begin{array}{c}42.89 \\
\%\end{array}$ & $27.47 \%$ & $\begin{array}{c}21.10 \\
\%\end{array}$ & $\begin{array}{c}57.23 \\
\%\end{array}$ & $\begin{array}{c}39.39 \\
\%\end{array}$ & $31.11 \%$ \\
\hline $\begin{array}{c}\text { Biaxial } \\
\text { Load } \\
\text { e/t=40\% }\end{array}$ & $\begin{array}{c}20.34 \\
\%\end{array}$ & $11.13 \%$ & $\begin{array}{c}8.35 \\
\%\end{array}$ & $\begin{array}{c}27.62 \\
\%\end{array}$ & $15.87 \%$ & $\begin{array}{c}12.25 \\
\%\end{array}$ & $\begin{array}{c}37.58 \\
\%\end{array}$ & $\begin{array}{c}23.50 \\
\%\end{array}$ & $19.67 \%$ \\
\hline
\end{tabular}

- In case of columns at room temperature condition under axial load; the increasing of $\mathrm{F}_{\mathrm{cu}}=25 \mathrm{~N} / \mathrm{mm}^{2}$ with percentage of $40 \%$ to be $\mathrm{F}_{\mathrm{cu}}=35 \mathrm{~N} / \mathrm{mm}^{2}$, consequently the residual load capacity is increased with percentage of $15 \%$. The increasing of $\mathrm{F}_{\mathrm{cu}}=25 \mathrm{~N} / \mathrm{mm}^{2}$ with percentage of $80 \%$ to be $\mathrm{F}_{\mathrm{cu}}=45 \mathrm{~N} / \mathrm{mm}^{2}$, consequently the residual load capacity is increased with percentage of $58 \%$.

- The residual load capacity of biaxially loaded column C2b23 (e/t=40\%) with $\mathrm{F}_{\mathrm{cu}}=45 \mathrm{~N} / \mathrm{mm}^{2}$ at firing time 3hr which equal (19.67\%) is nearly equal the residual load capacity of biaxially loaded column A1b12 $(\mathrm{e} / \mathrm{t}=25 \%)$ with $\mathrm{F}_{\mathrm{cu}}=25 \mathrm{~N} / \mathrm{mm}^{2}$ at firing time $1.5 \mathrm{hr}$ which equal $(19.86 \%)$.

- The residual load capacity of biaxially loaded column $\mathrm{C} 1 \mathrm{~b} 12(\mathrm{e} / \mathrm{t}=25 \%)$ with $\mathrm{F}_{\mathrm{cu}}=45 \mathrm{~N} / \mathrm{mm}^{2}$ at firing time 3hr which equal $(31.11 \%)$ is nearly equal the residual load capacity of biaxially loaded column A1b11 $(\mathrm{e} / \mathrm{t}=25 \%)$ with $\mathrm{F}_{\mathrm{cu}}=25 \mathrm{~N} / \mathrm{mm}^{2}$ at room temperature which equal $(32.54 \%)$.

- The residual load capacity of biaxially loaded column C1b11 (e/t=25\%) with $F_{c u}=45 \mathrm{~N} / \mathrm{mm}^{2}$ at room temperature which equal (57.23\%) is nearly equal the residual load capacity of axially loaded column A1a3 with $\mathrm{F}_{\mathrm{cu}}=25 \mathrm{~N} / \mathrm{mm}^{2}$ at firing time $3 \mathrm{hr}$ which equal $(53.12 \%)$.

- The residual load capacity of axially loaded column B1a3 with $\mathrm{F}_{\mathrm{cu}}=35 \mathrm{~N} / \mathrm{mm}^{2}$ at firing time $3 \mathrm{hr}$ which equal $(64.99 \%)$ is twice the residual load capacity of biaxially loaded column A1b11 (e/t=25\%) with $\mathrm{F}_{\mathrm{cu}}=25 \mathrm{~N} / \mathrm{mm}^{2}$ at room temperature which equal $(32.54 \%)$.

- The residual load capacity of biaxially loaded column C1b33 (e/t=40\%) with $\mathrm{F}_{\mathrm{cu}}=45 \mathrm{~N} / \mathrm{mm}^{2}$ at firing time 1.5hr which equal $(23.50 \%)$ is nearly equal the residual load capacity of biaxially loaded column $(\mathrm{e} / \mathrm{t}=40 \%)$ with $\mathrm{F}_{\mathrm{cu}}=25 \mathrm{~N} / \mathrm{mm}^{2}$ at firing time $\mathbf{1 . 5 h r}$ which equal $(11.13 \%)$.

- The residual load capacity of biaxially loaded column B1b22 (e/t=40\%) with $\mathrm{F}_{\mathrm{cu}}=35 \mathrm{~N} / \mathrm{mm}^{2}$ at firing time 1.5hr which equal $(15.87 \%)$ is nearly equal the residual load capacity of biaxially loaded column A1b13 $(\mathrm{e} / \mathrm{t}=25 \%)$ with $\mathrm{F}_{\mathrm{cu}}=25 \mathrm{~N} / \mathrm{mm}^{2}$ at firing time $3 \mathrm{hr}$ which equal $(15.27 \%)$. 
- The residual load capacity of biaxially loaded column B1b22 (e/t=40\%) with $\mathrm{F}_{\mathrm{cu}}=35 \mathrm{~N} / \mathrm{mm}^{2}$ at firing time 1.5hr which equal $(15.87 \%)$ is nearly twice the residual load capacity of biaxially loaded column A1a23 $(\mathrm{e} / \mathrm{t}=40 \%)$ with $\mathrm{F}_{\mathrm{cu}}=25 \mathrm{~N} / \mathrm{mm}^{2}$ at firing time $3 \mathrm{hr}$ which equal $(8.35 \%)$.

- The residual load capacity of biaxially loaded column B1b13 (e/t=25\%) with $\mathrm{F}_{\mathrm{cu}}=35 \mathrm{~N} / \mathrm{mm}^{2}$ at firing time $3 \mathbf{h r}$ which equal $(21.10 \%)$ is nearly equal the residual load capacity of biaxially loaded column A1b12 $(\mathrm{e} / \mathrm{t}=25 \%)$ with $\mathrm{F}_{\mathrm{cu}}=25 \mathrm{~N} / \mathrm{mm}^{2}$ at firing time $1.5 \mathrm{hr}$ which equal $(19.86 \%)$.

\section{SUMMARY AND CONCLUSIONS}

Results are presented, discussed and based on the analytical investigation; the following conclusions can be drawn:

1- Numerical analysis was found to be an effective method for analyzing the behaviour of fire exposed reinforced concrete columns under axial and biaxial loads.

2- For a high concrete characteristic strength, the column residual load capacity is increased as concrete characteristic strength increases.

3- Variation of the load capacity was low although the amount of $F_{c u}$ increased from $F_{c u}=25 \mathrm{~N} / \mathrm{mm}^{2}$ to be $F_{c u}=35 \mathrm{~N} / \mathrm{mm}^{2}$, but the load capacity improved to $58 \%$ by increasing $F_{c u}$ to be $45 \mathrm{~N} / \mathrm{mm}^{2}$, so that, the great variation was recorded when $F_{c u}$ increased from $25 \mathrm{~N} / \mathrm{mm}^{2}$ to $45 \mathrm{~N} / \mathrm{mm}^{2}$.

4- The residual load capacity is directly proportional to the concrete characteristic strength.

5- The residual load capacity of biaxially loaded column (e/t=25\%) with $\mathrm{F}_{\mathrm{cu}}=45 \mathrm{~N} / \mathrm{mm}^{2}$ at firing time $3 \mathrm{hr}$ is nearly equal the residual load capacity of biaxially loaded column $(\mathrm{e} / \mathrm{t}=25 \%)$ with $\mathrm{F}_{\mathrm{cu}}=25 \mathrm{~N} / \mathrm{mm}^{2}$ at room temperature.

\section{REFERENCES}

1- Mohammad Mansour Kadhum, Saif Salah Alkizwini, and Ali Abd-A'meer Alwash, 'Mathematical Models for Prediction of Some Mechanical Properties of Concrete Exposed to Burning', Department of Civil Engineering, Babylon University, 2013.

2- Nikhil Raut, 'Response of Elevated Strength Concrete Columns Under Fire-Induced Biaxial Bending', Ph.D Thesis, Michigan State University, Faculty of Engineering, 2011.

3- Farid. A. S., 'Effect of Fire Exposure on The Behaviour of Reinforced Concrete Columns under Axial and Eccentric Loads', Ph.D Thesis, Fayoum University, Faculty of Engineering, 2011.

4- Bekhite, and M., 'Behaviour of reinforced concrete columns exposed to fire', M.Sc.Faculty of Engineering, Thesis Cairo University, 2004.

5- Mohammed and W.H, 'Behaviour of Biaxially and Uniaxially Loaded HSC Square Short Columns Strengthened with Externally Applied FRP Laminates ', Msc thesis, June 2004.

6- El-Mihilmy, and M. 'Behaviour and Design of R.C.Short Columns Under Biaxial Bending', Msc thesis, Cairo University, Dec.1992.

7-British Standards Institution.BS 476: Part 8 `Test Methods and Criteria for the Fire Resistance of Building Construction` London, England, 1972 OR British Standard Specification “'BS.8110, Part 2 1985, BS.8110, Part1,1997.

8-Lin, C.H., Chen, S.T., and Huang, D.K., "Mechanical behavior of axially loaded RC columns," NSC 780410-E011-13, project report to NSC, Taipei, 1990.

9- Lin, C.H., Chen, S.T., and Tsai, C.H, 'Behavior of RC columns after fire ', NSC 77-0410-E011-09, project report to NSC, Taipei, 1988.

10- Lie, T.T., Rowe, T.T., and Lin, T.D., 'Residual Strength of Fire-Exposed Reinforced Concrete column ', ACI Publication SP 92-9, 1983.

11- ANSYS $^{\circledR}$. Manual, Version 13. 